\title{
Occurrence of organochlorine and organophosphorus pesticide residues in poultry feeds, raw and cooked eggs from selected farms in Ilala and Kibaha Districts, Tanzania
}

*MAHUGIJA, JAM; CHIBURA, PE; LUGWISHA, EHJ

Chemistry Department, University of Dar es Salaam, P.O. Box 35061 Dar es Salaam, Tanzania

*Corresponding author.E-mail addresses:mahugija@udsm.ac.tz; johnmahugija@yahoo.com

\begin{abstract}
This study assessed the levels of seventeen pesticides and metabolites residues in chicken feeds and raw eggs as well as the effects of processing methods on the levels in eggs in samples obtained from six poultry farms in Ilala and Kibaha districts, Tanzania. Extraction was performed by solid dispersion method and the extracts were cleaned-up by adsorption column chromatography. The analytes were determined by Gas ChromatographyMass Spectrometry (GC-MS). The highest mean concentrations of the contaminants in feeds and eggs were as follows, respectively: aldrin 0.62 and $2 \mathrm{mg} / \mathrm{kg}$, dieldrin 0.71 and $1.3 \mathrm{mg} / \mathrm{kg}$, total DDT 6.68 and $8.14 \mathrm{mg} / \mathrm{kg}$, total endosulfan 3.53 and $3.74 \mathrm{mg} / \mathrm{kg}$, total HCHs 0.91 and $1.21 \mathrm{mg} / \mathrm{kg}$, chlorpyrifos 12.2 and $0.59 \mathrm{mg} / \mathrm{kg}$, fenitrothion 4.9 and $0.64 \mathrm{mg} / \mathrm{kg}$ and pirimiphos methyl 22.11 and $1.6 \mathrm{mg} / \mathrm{kg}$. Chicken feeds were found to be the most contaminated followed by raw eggs and finally cooked eggs. Most of the concentrations were above the maximum residue limits (MRLs) indicating risks and concerns. Proper selection and preparation of poultry feeds could reduce the levels in the feeds and eggs.
\end{abstract}

DOI: https://dx.doi.org/10.4314/jasem.v22i2.6

Copyright: Copyright () 2018 Mahugija et al. This is an open access article distributed under the Creative Commons Attribution License (CCL), which permits unrestricted use, distribution, and reproduction in any medium, provided the original work is properly cited.

Dates: First received 13 December 2017; Received in revised form 19 January 2018; Accepted 07 February 2018

Keywords: Pesticides, Chicken, Feed, Eggs, Tanzania

Poultry feeds may contain chemical contaminants such as pesticides (Zhao et al., 2013) and can be sources of contamination of poultry products including eggs (Windal et al., 2009). Chicken eggs are important sources of nutrients to the human body. They are good sources of proteins, unsaturated fatty acids, vitamins and minerals (Bradley and King, 2004) and are consumed by many people worldwide. The presence of pesticides in such foods is of great concerns to the consumers (Tao et al., 2009; Wang et al., 2013).

Pesticides are known to cause many health effects to animals including human beings (WHO, 2010). Pesticides are widely used in agricultural and livestock production in Tanzania for control of pests during farming, transportation, processing and storage. Most of the poultry feeds are derived from agricultural sources. A study by Mahugija et al. (2017) found high levels of pesticide residues in maize grains, which are among the sources of poultry feeds in Tanzania. This suggested that the poultry feeds and poultry products could also contain high levels of pesticide residues. Therefore, this study was conducted to investigate the levels and status of residues of selected organochlorine and organophosphorus pesticides in poultry feeds and raw eggs. The study also assessed the effects of cooking on the pesticide residues in eggs.

\section{MATERIALS AND METHODS}

Study sites and sampling: Poultry feeds and eggs were collected from six poultry farms in Ilala and Kibaha Districts in Tanzania in December 2014 to March 2015. Four sampling sites were located in Kibaha district and two sites were located in Ilala district (Figure 1). The farms use feeds prepared from mixtures of products including maize bran, rice bran, sardines, fish, animal bones, cow blood, ground dried legume leaves and mineral premix. Composite poultry feed samples (500 g each) and eggs were collected from the farms. A total of 63 samples of poultry feeds and eggs were obtained from the farms. Each sample was wrapped in aluminium foil. In the laboratory, the feed samples were kept frozen at -18 ${ }^{\circ} \mathrm{C}$, while the eggs were stored in a refrigerator at 4 ${ }^{\circ} \mathrm{C}$ until extraction.

Preparation of samples, extraction and clean-up: The shells of the raw eggs were removed prior to processing. The effects of cooking were assessed through boiling the eggs with distilled water for 15 minutes, and then cooled and their shells were removed. Each of the samples was homogenized by grinding using mortar and pestle. The homogenized sample $(20 \mathrm{~g})$ was extracted by shaking with cyclohexane: ethyl acetate mixture $(1: 1 \mathrm{v} / \mathrm{v}, 70 \mathrm{~mL}$, then $50 \mathrm{~mL}$ and finally $40 \mathrm{~mL}$ ) in a flask; dried with anhydrous sodium sulfate (10-20 g) and concentrated 
to $2 \mathrm{~mL}$ using a rotary evaporator. Clean-up of the concentrated extracts was performed using florisil (10 g) and sodium sulfate $(5 \mathrm{~g})$ packed in a glass column $(10 \mathrm{~mm}$ i.d. x $32 \mathrm{~cm}$ ) and eluted with cyclohexane: ethyl acetate $(40 \mathrm{~mL})$ then concentrated in a rotary evaporator and made up to $2 \mathrm{~mL}$ in cyclohexane: acetone $(9: 1 \mathrm{v} / \mathrm{v})$ ready for analysis.

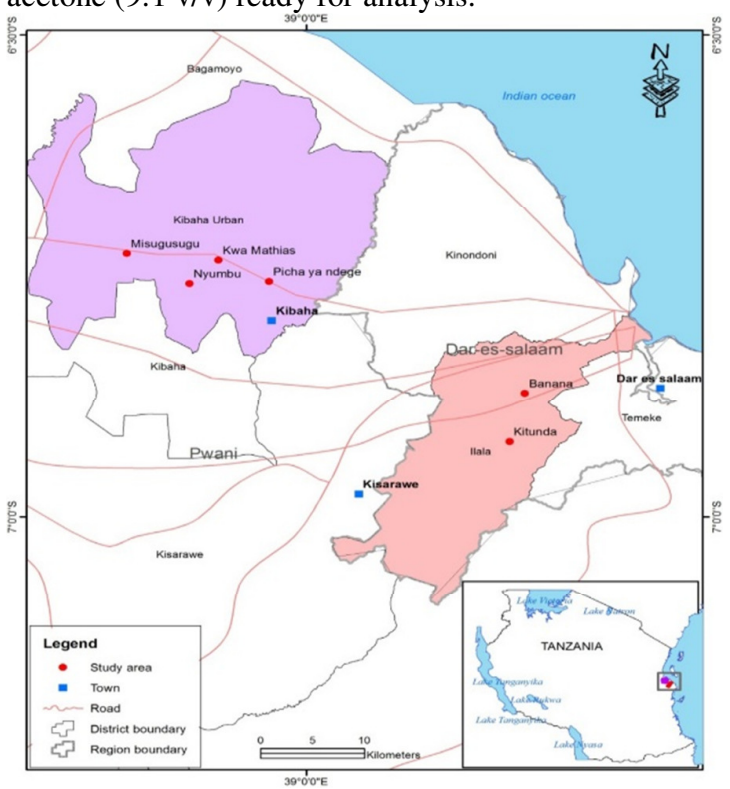

Fig 1: Map showing the sampling sites

Analytical quality assurance: Analytical quality assurance procedures included the use of analytical grade and high purity chemicals (Thermo Fisher Scientific, UK) and standards (Dr. Ehrenstorfer, Germany) and determination of blanks, recovery (accuracy), precision tests and detection limits. Procedural blank tests involved checking the solvents and reagents. The recovery tests were performed by spiking the matrix blanks at levels of 0.2, 0.5, 1.0, 2.0 and $5 \mu \mathrm{g} / \mathrm{kg}$ and the experiments were carried out with three replicates at each level. Detection limits were established based on signals that were three times higher than the noise level. The analytes were not detected in the procedural blanks. The recoveries of the analytes ranged from $82 \%$ to $115 \%$ and were acceptable with precision of relative standard deviation of $<10 \%$ (European Commission, 2015). The calibration curves were linear with correlation coefficients $\left(r^{2}\right)>0.9$. The detection limits varied from 0.0003 to $0.001 \mathrm{mg} / \mathrm{kg}$.

Gas chromatographic analysis and data analysis: The compounds in the purified extracts were quantified on a gas chromatograph coupled to a mass spectrometer (Agilent GC-MS), equipped with HP5MS capillary column, XL mass selective detector and autosampler. Oven temperature programme was
$90{ }^{\circ} \mathrm{C}$ held for $1 \mathrm{~min}$, raised to $180{ }^{\circ} \mathrm{C}$ at a rate of 30 ${ }^{\circ} \mathrm{C} / \mathrm{min}$ then to $260{ }^{\circ} \mathrm{C}$, at a rate of $4{ }^{\circ} \mathrm{C} / \mathrm{min}$. A $1 \mu \mathrm{L}$ sample was injected in splitless mode at $250{ }^{\circ} \mathrm{C}$ and purge flow of $3 \mathrm{~mL} / \mathrm{min}$. The carrier gas was helium at the flow rate of $2.2 \mathrm{~mL} / \mathrm{min}$ and the internal pressure was $150 \mathrm{kPa}$. The interface was heated at $300{ }^{\circ} \mathrm{C}$, the ion source temperature was $230^{\circ} \mathrm{C}$ and the mass spectrometer was operated in electron ionization and full scan mode in the range of 45 to $500 \mathrm{~m} / z$. Standards dissolved in cyclohexane:acetone $(9: 1 \mathrm{v} / \mathrm{v})$ were analyzed in each batch. The concentrations of working standards ranged from 0.5 to $2 \mu \mathrm{g} / \mathrm{mL}$. The retention times and mass spectra of the analytes in samples were compared with those of reference standards for identification of the compounds. The NIST mass spectral library and AMDIS programme were also used in the identification of the analytes. Peak heights were used for quantification of the analytes. Data analysis involved analysis of variance (ANOVA) and $t$-test to test for significance of variations using GraphPad Instat software (GraphPad Software, Inc. San Diego California, USA).

\section{RESULTS AND DISCUSSION}

Pesticide residues in poultry feeds: The organochlorine pesticide residues detected in the poultry feeds included aldrin, dieldrin, hexachlorocyclohexane $(\mathrm{HCH})$ isomers $(\alpha-, \beta-, \gamma$ - and $\delta$ - $\mathrm{HCH}$ ), endosulfan isomers ( $\alpha$ - and $\beta$-endosulfan) and dichlorodiphenyltrichloroethane (DDT) residues $\left(p, p^{\prime}-\right.$ and $o, p^{\prime}$-DDT, DDD and DDE). Their concentrations are presented in Table 1. Aldrin was detected in all the poultry feed samples and the concentrations ranged from 0.1 to $0.62 \mathrm{mg} / \mathrm{kg}$. Dieldrin was detected in samples from three sites with concentrations up to $0.71 \mathrm{mg} / \mathrm{kg}$. The concentrations of aldrin and dieldrin suggested contamination as pesticides as well as transformation of aldrin to dieldrin. The concentrations of total DDT in feeds ranged from 3.7 to $6.68 \mathrm{mg} / \mathrm{kg}$. The concentrations of DDT residues in feed samples were dominated by the metabolites (DDD and DDE) indicating contamination due to past use of DDT or significant degradation. The concentrations of total endosulfan detected in feed samples were up to $3.53 \mathrm{mg} / \mathrm{kg}$. The concentrations of $\alpha$-endosulfan were higher than $\beta$ endosulfan in samples collected from two sites, which indicated contamination with fresh technical endosulfan (ATSDR, 2013). In the feed samples collected from the other sites, only $\beta$-endosulfan was detected which can be due to contamination with old endosulfan and faster degradation of $\alpha$-endosulfan than $\beta$-endosulfan (ATSDR, 2013). $\mathrm{HCH}$ isomers were detected in the feeds with concentrations of total $\mathrm{HCHs}$ ranging from 0.36 to $0.91 \mathrm{mg} / \mathrm{kg}$ (Table 1). 
The concentrations of $\gamma-\mathrm{HCH}$ were the highest among the $\mathrm{HCH}$ isomers in most feed samples indicating technical lindane. The aldrin and dieldrin detected in feeds exceeded the maximum residue limit (MRL) of $0.02 \mathrm{mg} / \mathrm{kg}$. The concentrations of total DDT, total endosulfan and most $\mathrm{HCHs}$ in feeds exceeded the MRLs of $0.1,1.0$ and $0.01 \mathrm{mg} / \mathrm{kg}$, respectively (WHO/FAO, 2016). A study on feed samples in Italy reported aldrin at concentrations with mean $\pm \mathrm{SD}$ of $0.00453 \pm 0.00112 \mathrm{mg} / \mathrm{kg}$ (Panseri et al., 2013) that were lower than the concentrations found in the present study. The concentrations of DDT residues found in chicken feeds in the present study were greater than the levels found in feeds in Punjab (India), Italy and China where the mean concentrations of total DDT were up to $0.91,0.00412$ and $0.401 \mathrm{mg} / \mathrm{kg}$, respectively (Aulakh et al., 2006; Panseri et al., 2013; Zhao et al., 2013). The concentrations of the $\mathrm{HCHs}$ found in this study were comparable to the levels found by Aulakh et al. (2006) in Punjab (mean total $\mathrm{HCHs}=0.65 \mathrm{mg} / \mathrm{kg}$ ) but were generally greater than the levels found in poultry feed in China by Zhao et al. (2013) that were up to $0.01929 \mathrm{mg} / \mathrm{kg}$ for total HCHs.

Table 1: Mean concentrations of pesticide residues in chicken feeds $(\mathrm{mg} / \mathrm{kg}, \mathrm{n}=3$ )

\begin{tabular}{|c|c|c|c|c|c|}
\hline Pesticides/Metabolites & Misugusugu & Kwa Mathias & Nyumbu & Kitunda & Banana \\
\hline$\alpha-\mathrm{HCH}$ & $0.10 \pm 0.01$ & $0.10 \pm 0.10$ & ND & $0.30 \pm 0.02$ & ND \\
\hline$\beta-\mathrm{HCH}$ & $0.03 \pm 0.02$ & $0.003 \pm 0.002$ & $0.10 \pm 0.01$ & ND & $0.85 \pm 0.10$ \\
\hline$\gamma-\mathrm{HCH}$ & $0.14 \pm 0.04$ & $0.15 \pm 0.01$ & $0.17 \pm 0.01$ & $0.13 \pm 0.01$ & ND \\
\hline$\delta-\mathrm{HCH}$ & $0.14 \pm 0.01$ & $0.11 \pm 0.01$ & $0.10 \pm 0.01$ & $0.10 \pm 0.01$ & $0.06 \pm 0.03$ \\
\hline Total $\mathrm{HCH}$ & $0.41 \pm 0.03$ & $0.36 \pm 0.03$ & $0.37 \pm 0.02$ & $0.53 \pm 0.04$ & $0.91 \pm 0.09$ \\
\hline Aldrin & $0.24 \pm 0.10$ & $0.10 \pm 0.02$ & $0.28 \pm 0.20$ & $0.62 \pm 0.05$ & $0.56 \pm 0.04$ \\
\hline Dieldrin & ND & ND & $0.40 \pm 0.30$ & $0.71 \pm 0.10$ & $0.58 \pm 0.05$ \\
\hline$\alpha$-endosulfan & $1.30 \pm 0.30$ & $1.50 \pm 0.42$ & ND & ND & $\mathrm{ND}$ \\
\hline$\beta$-endosulfan & $0.90 \pm 0.21$ & $0.41 \pm 0.03$ & $3.53 \pm 1.90$ & ND & $2.12 \pm 1.52$ \\
\hline Total endosulfan & $2.20 \pm 0.40$ & $1.91 \pm 0.50$ & $3.53 \pm 1.90$ & ND & $2.12 \pm 1.52$ \\
\hline$p, p^{\prime}$-DDT & $0.22 \pm 0.02$ & $1.40 \pm 0.10$ & ND & $0.74 \pm 0.06$ & ND \\
\hline$o, p^{\prime}$-DDT & ND & ND & ND & ND & ND \\
\hline$p, p^{\prime}-\mathrm{DDD}$ & $1.25 \pm 0.20$ & $0.90 \pm 0.10$ & $2.28 \pm 0.30$ & $3.07 \pm 0.52$ & $3.00 \pm 0.60$ \\
\hline$o, p^{\prime}-\mathrm{DDD}$ & $0.50 \pm 0.10$ & $0.10 \pm 0.01$ & $1.42 \pm 0.20$ & $2.32 \pm 0.40$ & $2.11 \pm 0.50$ \\
\hline$p, p^{\prime}-\mathrm{DDE}$ & $1.83 \pm 0.40$ & $1.25 \pm 0.42$ & ND & $0.55 \pm 0.10$ & ND \\
\hline$o, p^{\prime}-\mathrm{DDE}$ & $0.63 \pm 0.10$ & $0.53 \pm 0.10$ & ND & ND & ND \\
\hline Total DDT & $4.43 \pm 1.50$ & $4.18 \pm 1.03$ & $3.70 \pm 0.50$ & $6.68 \pm 1.76$ & $5.11 \pm 1.23$ \\
\hline Chlorpyrifos & $2.52 \pm 0.20$ & $0.81 \pm 0.06$ & $11.00 \pm 1.32$ & $6.20 \pm 5.34$ & $12.20 \pm 1.34$ \\
\hline Fenitrothion & $0.03 \pm 0.01$ & $2.20 \pm 0.20$ & $4.90 \pm 0.30$ & ND & $2.50 \pm 0.20$ \\
\hline Pirimiphos methyl & $0.15 \pm 0.01$ & $11.00 \pm 0.80$ & $22.11 \pm 2.23$ & ND & $12.00 \pm 1.10$ \\
\hline
\end{tabular}

The organophosphorus pesticides detected in poultry feed samples were chlorpyrifos, fenitrothion and pirimiphos methyl (Table 1). Chlorpyrifos, fenitrothion and pirimiphos methyl were detected in 80 to $100 \%$ of the feed samples at concentrations ranging from 0.81 to $12.2,0.03$ to 4.9 and 0.15 to $22.11 \mathrm{mg} / \mathrm{kg}$, respectively. Chlorpyrifos concentrations in feeds exceeded the MRL of 0.05 $\mathrm{mg} / \mathrm{kg}$. Fenitrothion levels in feed samples were below the MRL of $6 \mathrm{mg} / \mathrm{kg}$. The concentrations of pirimiphos methyl residues in $60 \%$ of the feed samples exceeded the MRL of $7 \mathrm{mg} / \mathrm{kg}$ (WHO/FAO, 2016).

Pesticide residues in chicken eggs: The concentrations of organochlorine pesticide residues detected in eggs are presented in Table 2 and Table 3. The mean concentrations of total DDT in eggs ranged from 0.75 to $8.14 \mathrm{mg} / \mathrm{kg}$. The concentrations of DDD and DDE exceeded those of DDT indicating contamination with old DDT or significant degradation. Aldrin and dieldrin were detected in most egg samples and their mean concentrations were up to 2.0 and $1.3 \mathrm{mg} / \mathrm{kg}$, respectively. Endosulfan isomers $(\alpha$ and $\beta$ ) were detected in eggs with mean concentrations of total endosulfan of up to 3.74 $\mathrm{mg} / \mathrm{kg}$. The mean concentrations of $\beta$-endosulfan in all the raw eggs were relatively higher than of $\alpha$ endosulfan. This indicated that the contamination was due to old technical endosulfan which had undergone degradation. Some samples had higher concentrations of $\alpha$-endosulfan than $\beta$-endosulfan indicating contamination with fresh technical endosulfan (ATSDR, 2013). The mean concentrations of total $\mathrm{HCHs}$ in eggs ranged from 0.03 to $1.21 \mathrm{mg} / \mathrm{kg}$. The concentrations of $\gamma-\mathrm{HCH}$ were greater than the concentrations of other $\mathrm{HCH}$ isomers in most egg samples indicating contamination by technical lindane. Generally, the mean concentrations of DDT and $\mathrm{HCHs}$ residues in cooked eggs were lower than the concentrations in raw eggs. The concentrations of aldrin and dieldrin were greater in raw eggs than in cooked eggs except for aldrin in samples from two sites and the concentrations of endosulfan in raw eggs from three sites were greater than those in cooked eggs. These findings indicated that cooking transformed the pesticides into metabolites.. 
Table 2: Concentrations and occurrence of DDT residues in chicken eggs $(\mathrm{mg} / \mathrm{kg})$

\begin{tabular}{|c|c|c|c|c|}
\hline Sites & $\begin{array}{l}\text { Pesticides/ } \\
\text { Metabolites }\end{array}$ & $\begin{array}{l}\text { Raw eggs } \\
\text { (n=6/site) }\end{array}$ & $\begin{array}{l}\text { Cooked eggs } \\
\text { (n= 2/site) }\end{array}$ & $\begin{array}{l}\text { Detection } \\
\text { frequency (\%) }\end{array}$ \\
\hline Misugusugu & $\begin{array}{l}p, p \text {-DDT } \\
o, p \text {-DDT } \\
p, p \text {-DDD } \\
o, p \text {-DDD } \\
p, p \text {-DDE } \\
o, p \text {-DDE } \\
\text { Total DDT }\end{array}$ & $\begin{array}{l}0.10=0.11 \\
0.02=0.01 \\
2.10 \pm 2.51 \\
0.90=0.24 \\
1.16 \pm 1.58 \\
0.03 \pm 0.03 \\
4.31=4.30\end{array}$ & $\begin{array}{l}0.20=0.10 \\
0.004=0.01 \\
2.90=1.05 \\
0.50=0.20 \\
0.10=0.20 \\
0.10=0.10 \\
3.80=1.10\end{array}$ & $\begin{array}{l}100 \\
87.5 \\
87.5 \\
87.5 \\
75.0 \\
75.0 \\
100\end{array}$ \\
\hline Kwa Mathias & $\begin{array}{l}p, p^{\prime} \text {-DDT } \\
o, p-\mathrm{DDT} \\
p, p^{\prime} \text {-DDD } \\
o, p^{\prime}-\mathrm{DDD} \\
p, p^{\prime} \text {-DDE }\end{array}$ & $\begin{array}{l}2.36=2.21 \\
0.02=0.01 \\
2.89=1.77 \\
0.46=0.35 \\
1.35=1.10\end{array}$ & $\begin{array}{l}\text { ND } \\
\text { ND } \\
1.92=1.40 \\
1.70=1.10 \\
0.01=0.01\end{array}$ & $\begin{array}{l}75.0 \\
50.0 \\
100 \\
100 \\
100\end{array}$ \\
\hline Picha ya & $\begin{array}{l}o, p \text {-DDE } \\
\text { Total DDT } \\
p, p \text {-DDT }\end{array}$ & $\begin{array}{l}0.04 \pm 0.06 \\
7.12 \pm 5.43 \\
0.70 \pm 0.54\end{array}$ & $\begin{array}{l}\mathrm{ND} \\
3.63 \pm 2.20 \\
1.20 \pm 1.40\end{array}$ & $\begin{array}{l}50.0 \\
100 \\
100\end{array}$ \\
\hline Ndege & $\begin{array}{l}o, p \text {-DDT } \\
p, p \text {-DDD } \\
o, p \text {-DDD } \\
p, p \text {-DDE } \\
o, p \text {-DDE } \\
\text { Total DDT }\end{array}$ & $\begin{array}{l}0.06=0.06 \\
2.30=1.42 \\
0.89=0.90 \\
1.55=1.59 \\
0.20=0.38 \\
5.70=3.88\end{array}$ & $\begin{array}{l}\mathrm{ND} \\
1.70=1.3 \\
0.34=0.40 \\
2.8=1.26 \\
0.10=0.01 \\
6.14=3.77\end{array}$ & $\begin{array}{l}62.5 \\
100 \\
100 \\
100 \\
75.0 \\
100\end{array}$ \\
\hline Nyumbu & $\begin{array}{l}p, p-\mathrm{DDT} \\
o, p-\mathrm{DDT} \\
p, p \text {-DDD } \\
o, p \text {-DDD } \\
p, p \text {-DDE } \\
o, p \text {-DDE } \\
\text { Total DDT }\end{array}$ & $\begin{array}{l}0.20=0.32 \\
0.01=0.04 \\
1.45 \pm 1.29 \\
0.31=0.463 \\
0.60=0.53 \\
0.20 \pm 0.17 \\
2.77 \pm 1.52\end{array}$ & $\begin{array}{l}\text { ND } \\
0.04=0.02 \\
0.60=0.11 \\
0.11=0.04 \\
N D \\
N D \\
0.75=0.20\end{array}$ & $\begin{array}{l}37.5 \\
37.5 \\
100 \\
100 \\
50.0 \\
50.0 \\
100\end{array}$ \\
\hline Kitunda & $\begin{array}{l}p, p \text {-DDT } \\
o, p \text {-DDT } \\
p, p \text {-DDD } \\
o, p \text {-DDD } \\
p, p \text {-DDE } \\
o, p \text {-DDE } \\
\text { Total DDT }\end{array}$ & $\begin{array}{l}1.87 \pm 1.96 \\
0.31=0.75 \\
3.36=2.15 \\
0.55=0.74 \\
1.85 \pm 2.13 \\
0.20=0.17 \\
8.14=7.72\end{array}$ & $\begin{array}{l}0.77=0.30 \\
\mathrm{ND} \\
1.65 \pm 1.32 \\
0.20=0.08 \\
2.25=0.52 \\
0.02=0.01 \\
4.89 \pm 2.22\end{array}$ & $\begin{array}{l}75.0 \\
37.5 \\
100 \\
100 \\
87.5 \\
87.5 \\
100\end{array}$ \\
\hline Banana & $\begin{array}{l}p, p \text {-DDT } \\
o, p \text {-DDT } \\
p, p \text {-DDD } \\
o, p \text {-DDD } \\
p, p \text {-DDE } \\
o, p \text {-DDE } \\
\text { Total DDT }\end{array}$ & $\begin{array}{l}0.10=0.17 \\
0.01=0.01 \\
1.26=1.17 \\
0.11 \pm 0.15 \\
0.42 \pm 0.53 \\
0.06=0.07 \\
1.96=2.28\end{array}$ & $\begin{array}{l}0.12=0.03 \\
\mathrm{ND} \\
2.50=1.31 \\
0.41 \pm 0.20 \\
1.12=0.30 \\
\mathrm{ND} \\
4.15 \pm 1.43\end{array}$ & $\begin{array}{l}75.0 \\
37.5 \\
75.0 \\
75.0 \\
75.0 \\
62.5 \\
100 \\
\end{array}$ \\
\hline
\end{tabular}

The concentrations of total DDT in all of the eggs were above the MRL of $0.1 \mathrm{mg} / \mathrm{kg}$. Aldrin and dieldrin had higher levels than the MRL of $0.1 \mathrm{mg} / \mathrm{kg}$ in $47.6 \%$ of the eggs. The concentrations of endosulfan in $92.7 \%$ of the egg samples were above the MRL of $0.03 \mathrm{mg} / \mathrm{kg}$. All the concentrations of total $\mathrm{HCHs}$ detected in eggs were above the MRL of $0.001 \mathrm{mg} / \mathrm{kg}$ (WHO/FAO, 2016). The concentrations of the DDT residues found in eggs were greater than the levels reported by Ahmad et al. (2010) in Jordan (ranged from 0.005 to $0.600 \mathrm{mg} / \mathrm{kg}$ with a mean of $0.072 \mathrm{mg} / \mathrm{kg}$ ) and by Salar-Amoli and Esfahani (2015) in Tehran (mean $=0.00005 \mathrm{mg} / \mathrm{kg})$. A similar study by Polder et al. (2016) found relatively lower levels of DDT residues in free-range chicken eggs; total DDT ranged from 0.002 and $0.324 \mathrm{mg} / \mathrm{kg}$ lipid weight. The study by Aulakh et al. (2006) in Punjab, India reported concentrations ranging from 0.04 to $0.16 \mathrm{mg} \mathrm{kg}^{-1}$ for $\alpha-\mathrm{HCH}, \beta-\mathrm{HCH}$ and $\gamma-\mathrm{HCH}$ with total $\mathrm{HCH}$ mean concentration \pm SD of $0.26 \pm 0.012$ $\mathrm{mg} \mathrm{kg}^{-1}$ in poultry eggs that are similar to the findings in the present study.

Table 3: Concentrations and occurrence of aldrin, dieldrin, endosulfan and $\mathrm{HCH}$ residues in eggs $(\mathrm{mg} / \mathrm{kg})$

\begin{tabular}{|c|c|c|c|c|}
\hline Sites & Pesticide residues & $\begin{array}{l}\text { Raw eggs } \\
(\mathrm{n}=6 / \text { site })\end{array}$ & $\begin{array}{l}\text { Cooked eggs } \\
(\mathrm{n}=2 / \text { site) }\end{array}$ & $\begin{array}{l}\text { Detection } \\
\text { frequency }(\%)\end{array}$ \\
\hline \multirow{10}{*}{ Misugusugu } & Aldrin & $0.30=0.43$ & $1.10=0.10$ & 62.5 \\
\hline & Dieldrin & $0.69 \pm 1.53$ & $\mathrm{ND}$ & 62.5 \\
\hline & $\alpha$-endosulfan & $0.60 \pm 1.20$ & $0.50 \pm 0.05$ & 100 \\
\hline & $\beta$-endosulfan & $1.50=1.27$ & $0.30=0.20$ & 87.5 \\
\hline & Total endosulfan & $2.10 \pm 2.42$ & $0.80=0.60$ & 100 \\
\hline & $\alpha-\mathrm{HCH}$ & $0.04 \pm 0.04$ & $0.01 \pm 0.02$ & 100 \\
\hline & $\beta$-HCH & $0.01 \pm 0.01$ & $0.01 \pm 0.01$ & 87.5 \\
\hline & $\gamma-\mathrm{HCH}$ & $0.03 \pm 0.03$ & $0.04 \pm 0.01$ & 100 \\
\hline & $\hat{\delta}-\mathrm{HCH}$ & $0.02 \pm 0.02$ & $0.01=0.01$ & 100 \\
\hline & Total $\mathrm{HCH}$ & $0.10=0.10$ & $0.07 \pm 0.02$ & 100 \\
\hline Kwa & Aldrin & $2.00 \pm 1.56$ & $\mathrm{ND}$ & 75.0 \\
\hline \multirow[t]{9}{*}{ Mathias } & Dieldrin & $1.30=1.98$ & $0.20=0.01$ & 87.5 \\
\hline & $\alpha$-endosulfan & $0.40=0.48$ & $0.14=0.20$ & 87.5 \\
\hline & $\beta$-endosulfan & $1.49 \pm 2.22$ & $0.43=0.30$ & 87.5 \\
\hline & Total endosulfan & $1.89 \pm 2.69$ & $0.57=0.50$ & 100 \\
\hline & a-HCH & $0.02 \pm 0.01$ & $0.01 \pm 0.004$ & 100 \\
\hline & $\beta$-HCH & $0.04=0.09$ & $0.002 \pm 0.002$ & 100 \\
\hline & $\gamma-\mathrm{HCH}$ & $1.14=2.19$ & $0.01=0.06$ & 100 \\
\hline & $\hat{0}-\mathrm{HCH}$ & $0.01 \pm 0.01$ & $0.004 \pm 0.001$ & 100 \\
\hline & Total HCH & $1.21 \pm 2.29$ & $0.03 \pm 0.001$ & 100 \\
\hline Picha ya & Aldrin & $0.10=0.16$ & $0.20 \pm 0.02$ & 62.5 \\
\hline \multirow[t]{9}{*}{ Ndege } & Dieldrin & $1.20=1.54$ & $0.40=0.30$ & 100 \\
\hline & $\alpha$-endosulfan & $0.40=0.28$ & $0.60=0.20$ & 100 \\
\hline & $\beta$-endosulfan & $0.85=1.04$ & $1.14 \pm 1.50$ & 62.5 \\
\hline & Total endosulfan & $1.25 \pm 1.73$ & $1.74 \pm 1.70$ & 100 \\
\hline & $\alpha-\mathrm{HCH}$ & $0.02 \pm 0.02$ & $0.01 \pm 0.01$ & 100 \\
\hline & $\beta$-HCH & $0.04 \pm 0.08$ & $0.01 \pm 0.003$ & 87.5 \\
\hline & $\gamma-\mathrm{HCH}$ & $0.15 \pm 0.2$ & $0.02 \pm 0.004$ & 100 \\
\hline & $\delta-\mathrm{HCH}$ & $0.01 \pm 0.01$ & $0.01 \pm 0.001$ & 100 \\
\hline & Total HCH & $0.22 \pm 0.34$ & $0.05 \pm 0.003$ & 100 \\
\hline \multirow[t]{10}{*}{ Nyumbu } & Aldrin & $0.45 \pm 0.76$ & $0.10 \pm 0.01$ & 87.5 \\
\hline & Dieldrin & $1.30=1.16$ & $0.30=0.20$ & 100 \\
\hline & $\alpha$-endosulfan & $0.60=0.57$ & $0.65=0.10$ & 87.5 \\
\hline & $\beta$-endosulfan & $1.50 \pm 2.08$ & ND & 37.5 \\
\hline & Total endosulfan & $2.10=2.65$ & $0.65 \pm 1.00$ & 87.5 \\
\hline & $\alpha-\mathrm{HCH}$ & $0.024 \pm 0.02$ & $0.01 \pm 0.001$ & 100 \\
\hline & $\beta$-HCH & $0.033=0.02$ & $0.01=0.002$ & 100 \\
\hline & $\gamma-\mathrm{HCH}$ & $0.114 \pm 0.07$ & $0.01 \pm 0.003$ & 100 \\
\hline & $\delta-\mathrm{HCH}$ & $0.006 \pm 0.01$ & ND & 62.5 \\
\hline & Total HCH & $0.18 \pm 0.12$ & $0.03 \pm 0.01$ & 100 \\
\hline \multirow[t]{10}{*}{ Kitunda } & Aldrin & $0.10=0.10$ & $0.10=0.01$ & 62.5 \\
\hline & Dieldrin & $0.60 \pm 1.37$ & $0.20=0.01$ & 62.5 \\
\hline & $\alpha$-endosulfan & $1.00 \pm 0.53$ & $0.80=0.10$ & 100 \\
\hline & $\beta$-endosulfan & $1.33=1.33$ & $2.94 \pm 0.84$ & 87.5 \\
\hline & Total endosulfan & $2.33=1.37$ & $3.74=1.20$ & 100 \\
\hline & $\alpha-\mathrm{HCH}$ & $0.01=0.01$ & $0.01 \pm 0.002$ & 100 \\
\hline & $\beta$-HCH & $0.01 \pm 0.01$ & $0.002 \pm 0.001$ & 87.5 \\
\hline & $\gamma-\mathrm{HCH}$ & $0.02 \pm 0.01$ & $0.02 \pm 0.001$ & 100 \\
\hline & $\delta-\mathrm{HCH}$ & $0.01 \pm 0.01$ & $0.002 \pm 0.002$ & 100 \\
\hline & Total HCH & $0.05=0.04$ & $0.034=0.001$ & 100 \\
\hline \multirow[t]{4}{*}{ Banana } & Aldrin & $0.80=0.95$ & $0.07 \pm 0.01$ & 62.5 \\
\hline & Dieldrin & $0.20=0.28$ & $0.12 \pm 0.01$ & 62.5 \\
\hline & $\alpha$-endosulfan & $0.80=0.75$ & $1.30=0.02$ & 87.5 \\
\hline & $\beta$-endosulfan & $1.20 \pm 2.05$ & $2.07 \pm 1.10$ & 87.5 \\
\hline
\end{tabular}

The concentrations of total HCHs in poultry eggs reported by Tao et al. (2009) in Beijing, China $\left(0.00158 \pm 0.000519 \mathrm{mg} \mathrm{kg}^{-1}\right)$ and the concentrations of endosulfan reported by Vanitha et al. (2014) in chicken eggs in Chennai, India (ranged from $0.025 \pm$ 0 to $0.03125 \pm 0.00377 \mathrm{mg} \mathrm{kg}^{-1}$ ) were lower than the present findings.

The study by Salar-Amoli and Esfahani (2015) in Tehran, Iran detected lower levels of aldrin (up to $0.120 \mu \mathrm{g} / \mathrm{kg}$ ) and dieldrin (mean $=0.015 \mu \mathrm{g} / \mathrm{kg}$ ) in eggs than those found in this study. The levels of dieldrin and $\mathrm{HCHs}$ were comparable to the levels 
found in the study by Polder et al. (2016) that ranged from 0.002 to $98.791 \mathrm{mg} / \mathrm{kg}$ lipid weight, but the levels of endosulfan found in that study were lower than the levels found in the present study.

The organophosphorus pesticides detected in most eggs were chlorpyrifos, fenitrothion and pirimiphos methyl. Their concentrations and detection frequencies are presented in Table 4. The mean concentrations of chlorpyrifos, pirimiphos methyl and fenitrothion in eggs were up to $0.59,1.6$ and 0.64 $\mathrm{mg} / \mathrm{kg}$, respectively. All the concentrations of chlorpyrifos and pirimiphos methyl detected in eggs were above the MRL of $0.01 \mathrm{mg} / \mathrm{kg}$ and the detected concentrations of fenitrothion were above the MRL of $0.05 \mathrm{mg} / \mathrm{kg}$ (WHO/FAO, 2016).

Variation of the pesticide residues among samples: There were significant differences in the concentrations of most of the pesticide residues among the samples $(p<0.05)$. Generally, the highest mean concentrations of most of the pesticide residues were found in chicken feeds and raw eggs. Most of the concentrations of the residues in cooked eggs were lower than those in raw eggs, indicating that cooking reduced the pesticide residues, probably due to transformations. On average, the concentrations of the residues in cooked eggs were less by $5.4 \%$ to $94.6 \%$ than the concentrations in raw eggs.

Conclusion: High levels of the pesticide residues were detected in chicken feeds and eggs and most of them exceeded the maximum residue limits indicating risks and concerns for public health. The findings indicated contamination due to past use as well as fresh applications of the pesticides.

\begin{tabular}{|c|c|c|c|c|}
\hline Sites & Pesticides & $\begin{array}{l}\text { Raw eggs } \\
\text { (n=6/site) }\end{array}$ & $\begin{array}{l}\text { Cooked eggs } \\
\text { (n=2/site) }\end{array}$ & $\begin{array}{l}\begin{array}{l}\text { Detection } \\
\text { frequency }(\%)\end{array} \\
\text { fre }\end{array}$ \\
\hline \multirow[t]{3}{*}{ Misugusugu } & Chlospyrifos & $0.40=0.59$ & $0.13=0.04$ & 75.0 \\
\hline & Fenitrochion & $0.33=0.68$ & $0.04=0.05$ & 100 \\
\hline & Pirimiphos methyl & $1.60=3.20$ & $0.21=0.20$ & 100 \\
\hline \multirow[t]{3}{*}{ Kwa Mathias } & Chlospynifos & $0.59=0.77$ & $\mathrm{ND}$ & 50.0 \\
\hline & Fenitrochion & $0.64=0.92$ & $0.004=0.001$ & 100 \\
\hline & Pirimiphos methyl & $0.31=0.44$ & $0.02 \pm 0.01$ & 100 \\
\hline Picha ya & Chlospyrifos & $0.20=0.40$ & $\mathrm{ND}$ & 25.0 \\
\hline \multirow[t]{2}{*}{ Ndege } & Fenitrothion & $0.13=0.10$ & $0.18=0.05$ & 100 \\
\hline & Pirimiphos methy! & $0.61=0.45$ & $0.86=0.10$ & 100 \\
\hline \multirow{3}{*}{ Nyumbu } & Chlospyrifos & $0.20=0.15$ & ND & 62.5 \\
\hline & Fenitrothion & $0.13=0.09$ & $0.01=0.01$ & 100 \\
\hline & Pirimiphos methyl & $0.64=0.44$ & $0.03=0.02$ & 100 \\
\hline \multirow{3}{*}{ Kitunda } & Chloxpyifos & $0.10=0.20$ & $\mathrm{ND}$ & 12.5 \\
\hline & Fenitrochion & $0.15=0.07$ & $0.17=0.20$ & 100 \\
\hline & Pirimiphos methyl & $0.61=0.45$ & $0.79=0.10$ & 100 \\
\hline \multirow[t]{3}{*}{ Banana } & Chlospyrifos & $0.26=0.29$ & $\mathrm{ND}$ & 37.5 \\
\hline & Fenitrothion & $0.12=0.11$ & $0.16=0.04$ & 75.0 \\
\hline & Pirimiphos methyl & $0.60=0.53$ & $0.80=0.11$ & 87.5 \\
\hline
\end{tabular}

The highest concentrations were found in feed samples. The results indicated that cooking reduced the pesticide residues. The regulatory agencies should regularly monitor the practices in poultry farming and check the sources of poultry feeds.
Acknowledgements: The authors are grateful to the African Network for the Chemical Analysis of Pesticides (ANCAP) for support. GC-MS analyses were performed at the Department of Chemistry, Makerere University. Dr. J. Wasswa and Mr. Christopher are appreciated for assistance.

\section{REFERENCES}

Ahmad, R; Nida'M, S; Estaitieh, H (2010). Occurrence of organochlorine pesticide residues in eggs, chicken and meat in Jordan. Chemosphere 78: 667-671.

ATSDR (Agency for Toxic Substances and Disease Registry) (2013). Toxicological profile for endosulfan. US Department of Health and Human Services, Atlanta.

Aulakh, RS; Gill, JPS; Bedi, JS; Sharma, JK; Joia, BS; Ockerman, HW (2006). Organochlorine pesticide residues in poultry feed, chicken muscle and eggs at a poultry farm in Punjab, India. $J$. Sci. Food Agric. 86: 741-744.

Bradley, FA; King, AJ (2004). Eggs basics for the consumer: Packaging, storage and nutritional information. University of California, Division of Agriculture and Natural Resources, Publication 8154.

European Commission (2015). Guidance document on analytical quality control and method validation procedures for pesticides residues analysis in food and feed, Doc No. SANTE/11945/2015, European Commission.

Mahugija, JAM; Kayombo, A; Peter, R (2017). Pesticide residues in raw and processed maize grains and flour from selected areas in Dar es Salaam and Ruvuma, Tanzania. Chemosphere 185: 137-144.

Panseri, S; Biondi, PA; Vigo, D; Communod, R; Chiesa, LM (2013). Occurrence of organochlorine pesticide residues in animal feed and fatty bovine tissue. In: Innocenzo Muzzalupo (ed) Food Industry, InTech, Milan, Chapter 13, pp 262-283.

Polder, A; Müller, MB; Brynildsrud, OB; De Boer, J; Hamers, T; Kamstra, JH; Lie, E; Mdegela, RH; Moberg, H; Nonga, HE; Sandvik, M (2016). Dioxins, PCBs, chlorinated pesticides and brominated flame retardants in free-range chicken eggs from peri-urban areas in Arusha, 
Tanzania: levels and implications for human health. Sci. Total Environ. 551: 656-667.

Salar-Amoli, J; Ali-Esfahani, T (2015). Determination of hazardous substances in food basket eggs in Tehran, Iran. Vet. Res. Forum 6: 155-159.

Tao S; Liu, WX; Li, XQ; Zhou, DX; Li, X; Yang, YF; Yue, DP; Coveney, RM (2009). Organochlorine pesticide residuals in chickens and eggs at a poultry farm in Beijing, China. Environ. Pollut. 157: 497-502.

Vanitha, P; Chandra, GS; AshaRajini, R; Sivachandran, M; Venukopalan, K (2014). Estimation of organochlorine pesticide residues in poultry meat and egg. Ind. J. Vet \& Anim. Sci. Res. 43: 121-130.

Wang, S; Wang, Z; Zhang, Y; Wang, J; Guo, R (2013). Pesticide residues in market foods in Shaanxi Province of China in 2010. Food Chem. 138: 2016-2025.
Windal, I; Hanot, V; Marchi, J; Huysmans, G; Van Overmeire, I; Waegeneers, N; Goeyens, L (2009). PCB and organochlorine pesticides in home-produced eggs in Belgium. Sci. Total Environ. 407: 4430-4437.

World Health Organization (WHO) (2010). Exposure to highly hazardous pesticides: A major public health concern, WHO, Geneva.

WHO/FAO (2016). Pesticide residues in food and feed, Codex Alimentarius, International Food Standards, WHO/FAO, Rome.

Zhao, L; Dong, YH; Wang, H (2013). Residues of organochlorine pesticides and polycyclic aromatic hydrocarbons in farm-raised livestock feeds and manures in Jiangsu, China. Sci. Total Environ. 450-451: 348-355. 